\title{
The Combination of Entrepreneurship-Innovation Education and Geoscience Education in China Higher Education
}

\author{
Lina $\mathrm{Lu}^{1, \mathrm{a}}$, Jing $\mathrm{Li}^{1, \mathrm{~b}}$ Ming Yang ${ }^{1, \mathrm{a}}$ and Baojun $\mathrm{Li}^{1, \mathrm{a}}$ \\ ${ }^{1}$ Institute of Disaster Prevention, Yanjiao, Hebei, 065201, China, \\ alulina@cidp.edu.cn, ${ }^{b} 102$ lij@163.com
}

Keywords: entrepreneurship-innovation education, geoscience, innovative talents.

\begin{abstract}
Entrepreneurship-innovation education becomes more and more important in China higher education. Nowadays, Chinese geoscience education faces challenges, especially lack of entrepreneurship-innovation talents and "employment difficulty". This paper tries to combine entrepreneurship-innovation education with gecoscience education for enhancing the development of entrepreneurship-innovation education. The author analyzes the situation of entrepreneurshipinnovation education and geoscience education in China colleges or univesities, problems about entrepreneurship-innovation education in geoscience development, and solutions to the problems. Innovation of practice teaching in geoscience, industry-university-research amalgamation, and making full use of modern education technology may be three good ways to solve the problems.
\end{abstract}

\section{Introduction}

Nowadays, entrepreneurial level and innovative results determine the economic development degree between countries and countries, areas and areas. They also become the increasingly significant driving force for social and economic development in our country. Entrepreneurshipinnovation is an important channel for people to change their destiny, more importantly, also the key for a country to obtain core competence. Our society is in the transition stage at present and facing the unprecedented challenges. While geoscience education and mineral mining economics are up against the tough time. How to solve the increasingly serious problem of "employment difficulty" becomes one of the challenges. How to settle the problem "employment difficulty" in geoscience education? Its essence is how to promote entrepreneurship-innovation education. This article mainly interprets entrepreneurship-innovation education and geoscience education in China higher education, and try to find the integration path between the two education. It lays a theoretical foundation for domestic colleges or universities which cultivate geoscience students.

\section{Entrepreneurship-Innovation Education and Geoscience Education}

\subsection{Entrepreneurship-Innovation Education at Abroad}

Entrepreneurship-innovation education stems from the United States. In the 1930s, Frederick Emmons Terman, who was the professor at Stanford University, advocated the idea of "Steeple Building" and "Community of Technical Scholars", proposed the conception of forming a partnership between academia and industry. This made Stanford University go to a new stage. He invested his students to set up HP(Hewlett Packard), founded the Stanford Industrial Park and established Silicon Valley. He created a paradigm of the combination between production and study, which caused all countries to follow. This example became the intensive impetus to promote local social and economic development, and also the primary cradle for entrepreneurship-innovation education.

In the 1970s, American educational circle put forward the goal of cultivating cross-century talents with innovative spirit which possess the charecterristc of letting students acquire new knowledge, training students' analytical ability and original creation spirit.

In the 1980s, successful entrepreneurs who start their business from scientific and technological innovation, eg. Bill Gates, raised the "entrepreneurial revolution". It tremendously promoted the development of American entrepreneurship education in colleges and universities. This kind of entrepreneurial activities had brought obvious economic benefit. 
Cultivating innovative talents not only has brought national governments' attention, but also has aroused the concerrn of UNESCO(united nations educational scientific and cultural organization). UNESCO considers that exploiting innovative ability as the "one of the three pieces of educational traffic permit” for facing the future.

\subsection{Entrepreneurship-Innovation Education in China}

The university innovation education in our country originated in 1984. Compared with overseas, the innovation of the higher education entrepreneurship education in our country is tardy. For a long time, the cultivation of innovative spirit on college students is insufficient in the traditional higher education, due to the influence of planned economy. When the constantly improvement of the socialist market economy and the means of economic development transformation happened, the employment structure altered and traditional education must face the severe challenges. The problem of college students "employment diffculty" is just the concentrated manifestation of the personnel cultivating model of traditional education. Entrepreneurship-innovation education becomes extremely important during the social development in our country.

Ever since the first college students entrepreneurship design contest hosted in Tsinghua University in 1998, entrepreneurship-innovation education developed rapidly. In 2002 the Ministry of Education launched nine universities as entrepreneurship education pilot work. This stands for the entrepreneurship-innovation education in our country reached the diversifying development stage, and entrepreneurship-innovation education was mainly guided by the government. The Ministry of Education initiates the constructive project, such as "College students' innovative entrepreneurial training plan”, “College students' training mode innovation experimental zone” etc. to promote the cultivation of innovative and entrepreneurial talents. These measures made in recent years was aimed to carry out the work of the entrepreneurship-innovation education in our country, and these measures got unprecedented progress.

\subsection{Geoscience Education in China}

Geological education has fostered millions talents in total for our country till now. Geological education is now comparatively perfect and sitting at the best development position in history. In spite of that, in terms of geological education of cultivating the pioneering, practicing and innotivating talents still faces manny challenges. Along with the development of geological work, Geological science, technology progress and innovation need a multitude of innovative geological talents. The cultivation of the innovative geological talent resources has already become part of the strategy of reinvigorating China through human resource development. The Decision of the State Council on Strengthening Geological Work pinpoints that our country is still lack of macro strategic planning and guidance to geological education, and short of the medium and long-term geological talents demand forecasting. Mingyuan $\mathrm{Gu}$ indicated that we should seize the gist of reform talents training model, instead of the purely force-feeding education methods. The entrepreneurshipinnovation education in geoscience is still in its infancy in China.

Fostering innovative geological talents is the need of propelling the rapid development of geoscience. The contemporary science and technology has four essential characteristics. They are: firstly the technological knowledge of discipline grows explosively, secondly scientific and technological achievements industrialization cycle is shortened, thirdly scientific theory develops in advance, ultimately the science and technology globalization is speeding up. Geological science and technology also has the basic characteristics of the above four aspects. We must training geological talents to tackle the restraint of resources and environmental factors on the economic development by applying the geological science and technology innovation.

As we all know, at present, the recoverable resources decline in our country, and the bulk mineral degree of dependence on imported is increasing. The lack of mineral resources has become the "bottle neck" of economic development in China. Meanwhile, the conflict between economic and social development and ecological construction and environmental protection is increasingly outstanding. In order to solve these problems, the necessity of entrepreneurship-innovation education in geoscience stands out. 


\section{Problems about Entrepreneurship-Innovation Education in Geoscience Development}

In the entrepreneurship-innovation education of geoscience, the students mainly exist the following problems:

First of all, part of the students are not interested in geoscience and just aiming for the credit to get the college diploma. Secondly, students are still at the state of "only book theory", also limitted by textbook knowledge and cannot learn to broaden their horizon. Thirdly, they have been recieving knowledge in a passive way and are lack of innovative thinking, and couldn't come up with the unique idea to the question as well.

As for teachers, the problems are: on one hand, some teachers only accomplish the school arrangement of the teaching task, on the another, the knowledge they are teaching for the moment is far too antique and cannot interact with the advanced knowledge. Last but not the least, they neglect the cultivation of innovating and practicing competence to students.

Table1 Information about graduates from geoscience academic division of China universities/colleges in 2015

\begin{tabular}{|c|c|c|c|c|c|c|c|}
\hline \multirow[t]{2}{*}{ University/college } & \multirow{2}{*}{$\begin{array}{l}\text { graduates } \\
\text { amount }\end{array}$} & \multicolumn{2}{|c|}{$\begin{array}{l}\text { Further } \\
\text { education }\end{array}$} & \multirow{2}{*}{$\begin{array}{l}\text { Direct } \\
\text { employ- } \\
\text { ment }\end{array}$} & \multirow[t]{2}{*}{ Others } & \multirow{2}{*}{$\begin{array}{l}\text { Employ- } \\
\text { ment } \\
\text { rate(\%) }\end{array}$} & \multirow{2}{*}{$\begin{array}{l}\text { Promotion } \\
\text { rate(\%) }\end{array}$} \\
\hline & & $\mathrm{CHN}$ & abroad & & & & \\
\hline Peking University & 85 & 51 & 26 & 4 & 4 & $95.29 \%$ & $90.59 \%$ \\
\hline $\begin{array}{l}\text { Chengdu University } \\
\text { of Technology }\end{array}$ & 538 & 102 & 3 & 382 & 51 & $90.52 \%$ & $19.52 \%$ \\
\hline $\begin{array}{l}\text { Institute of Disaster } \\
\text { Prevention }\end{array}$ & 346 & 93 & 1 & 223 & 29 & $91.62 \%$ & $27.17 \%$ \\
\hline Nanjing University & 108 & 60 & 8 & 38 & N/A & $98.15 \%$ & $62.96 \%$ \\
\hline $\begin{array}{l}\text { University of Science \& } \\
\text { Technology of China }\end{array}$ & 205 & 109 & 31 & 49 & 16 & $92.20 \%$ & $68.29 \%$ \\
\hline Tongji University & 67 & 33 & 11 & N/A & N/A & $97.55 \%$ & $65.67 \%$ \\
\hline Chang'an University & 313 & 85 & 2 & 212 & 14 & $95.53 \%$ & $27.80 \%$ \\
\hline
\end{tabular}

I counted the graduation whereabouts from geoscience academic division of domestic main geological colleges and universities in geoscience graduates in 2015(table 1). This sheet illustrates that The university employment rate is above $90 \%$ in 2015 and the ratio of further education ranges from $20 \%$ to $90 \%$. We can see the "employment diffculty" in geoscience students from the ratio of further education. At the same time, along with the influence of world economic slow recovery and the declination of domestic economic growth, China's mineral industry the decade of "golden period" came to an end in 2013, which only make employment worse. To alleviate the severe pressure of employment, a small part of students choose to start up business and a large part of them choose to further their study. The reasons of further education are disparate. A small amount of students are aiming for obtaining more professional knowledge. Of course some of them are just trying to get a higher credentials to increase the leverage on employment. There are some students belong to follow suit.

In terms of employers, the most compelling inner qualities of the undergranduates are specialized knowledge, technological level, practicing ability, independent learning capability and innovation spirit. The external conditions they value the most are major, education background and graduate school. By far, a significant reason of "employment diffculty" is that domestic colleges and universities cultivate the geoscience professional students lacking in inner quality.

\section{Solution to the problems}

\subsection{Innovation of Practice Teaching in Geoscience}

Basic research personnels with high quality, profound basic knowledge,wide knowledge and strong competence are more needed in geoscience field. The practice teaching should follow the discipline development and head for the direction of the design and comprehensive development. We should put emphasis on student should not only have a solid academic foundation but also have the ability of flexibly using multidisciplinary knowledge. During the innovation of practice teaching in 
geoscience, we should take enhancing students' operational ability, analythetic ability,the competence of extracting information and innovative ability as the goal. We also change cognition and inheritance into research and innovation.

\subsection{Industry-University-Research Amalgamation}

The industry-university-research amalgamation means strongly promote integrating resources and complement each other's advantages between university, industry and reaearch institution. Thus, we can achieve of tranforming research achievements into actual productivity. Its essence is to solve the problem of talent training and combining science and technology and economy. So as to propel enterprise independent innovation and improve market competitiveness, promote education, science and technology and economic coordinated development and comprehensive progress. The entrepreneurship-innovation education of colleges and universities should take the practicing activities as the carrier to reinforce the cooperation of universities and geological exploration entreprise by fostering oriented talents. In the meantime, enterprises provide a large number of talents support and internship for entrepreneurship-innovation education in colleges and universities. Entreprises should get involved in curriculum setting and adjustment. Distinctive courses should be set up to let students master the distinctive employability skills, expand employment and increase the employment competence of geoscience students. The scientific research activities and scientific research achievements should be invested into education resources in real time and encourage students get into scientific research. Open the professional laboratory and create a strong academic environment and atmosphere to Train high level, research-oriented learning elites and forge a new generation of high quality innovative and entrepreneurial talents in geoscience.

\subsection{Make full Use of Modern Education Technology}

In recent years, geological science has gradually developed from traditional qualitative research to quantitative research due to the widespread use of new technology and new method. The practice teaching must keep up with The time and update technical equipments and apparatus. We should take educational informationalization construction to the next level via applying information resource service in teaching. Educational informationalization construction is an important approach to achieve the modernization of education development in our country. We should put more efforts into the aspects of education information infrastructure, resource construction, talents training and education system application level and so on. The constuction of the practice teaching website and virtual practice system should be established as soon as possible, which suggests digitizing those different laboratory material and practice teaching material of field practice base.

\section{Expectation}

Accompany with the rapid development of social economy, the demand is higher and higher to energy, resources and environment. Gescience is playing a more cucial role in our society. Entrepreneurship-innovation education is the important approach to improve the innovative capability of college students' practice and should be followed through during the whole practice education process. Entrepreneurship-innovation education is the only path to improve the ability of college students' social adaptation and sustainable development. It needs colleges and universities and society to create a machanism of together as one, mutual benefit, resources sharing and complement each other's advantages, and commonly build a good environment conducive to creative talents cultivation. It also needs education workers take a further step in changing education idea, continue to strengthen the reform of the teaching content and teaching method to break the blockage. To implement internal amalgamation and three-dimensional teaching. In order to provide an excellent innovation entrepreneurship development space for college students, we should deeply integrate entrepreneurship-innovation education with professional education, intensify the practice of innovative entrepreneurial training and propel students' comprehensive coordinated development in knowledge, ability and quality.

The study was jointly supported by the teaching research-innovation foundation (Nos. JY2016A01) and quality course construction program (Nos. JPJS2016004). 


\section{References}

[1] Cao Shengli. The Innovative Country and Cultivate Innovative-Entrepreneurial Talents Construction-About a few Discussion on the Question of "The Third Education traffic permit" [J]. China Higher Education Research, 2008, (05): 59-62.

[2] Chen Yong. Primary Discussion on Cultivation of Geochemical Innovation Thought for Geology Undergraduates [J]. Chinese Geological Education, 2013, (03): 48-51.

[3] Gu Mingyuan. Study and Interpretation on State Planning Outline f or Medium and Long-term Education Reform and Development(2010-2020) [J].Journal of Higher education, 2010, (07): 1-6.

[4] Li Xuan. Study on Rule of Growing-up Process and Cultivating Mode of Innovative Geologics Elites [D]. China University of Geosciences (Beijing),2006.

[5] Liu Yan, Yan Guodong, Meng Wei, et al. Deeper Integration between Innovation Entrepreneur -ship Education and professional education [J]. China University Teaching, 2014, (11): 35-37

[6] Shen Jianian, Feng Jinlai, Li Jiaona, et al. Geochemical Undergraduate Training Model for Business Needs [J]. Discipline Exploration, 2015, (03): 30-32.

[7] Tai Feng, Gao Guohua, Song Guangqing, et al. On Enterprises Cooperation Education Pattern Based on Engineering Education [J]. Research and Exploration in Laboratory, 2013, (10): 175-177. [8] Wang Fatang, Han Xiaohui, Lu Qi. Enlightenment of the Development of Innovation Education Abroad on Innovative Education in Chinese Colleges or Universities[J]. Journal of Shandong Youth Administrative Cadres College, 2004, (04): 74-77.

[9] Wang Ge, Cao Shengli, Liu Qiaofei. Deepen the Higher Education Reform and Strongly Promote Entrepreneurship-Innovation Education's Development-The Summary of National colleges and universities of Entrepreneurship-Innovation Education Peak BBS [J]. China Higher Education Research, 2009, (06): 54-56.

[10] Wu Ganguo. Reform on Talents Cultivation Models and Cultivation of Excellent Geosciences Talents [C]. Chinese Geological Education, 2011.

[11] Xu Yanhua, Frederick Emmons Terman Higher Education Thought and the Practice Research [D]. Hebei University, 2011.

[12] Yu Jicong, Duan Yichun, Zhao Lianrong, et al. Current Situation and Development Research of Chinese Geological Education [J]. Chinese Geological Education, 2011, (01): 3-13.

[13] Yu Tao, Yang Zhongfang, Hou Qingye, et al. Thinking about Postgraduate Education in the Professional Degree of Geochemistry [J]. Chinese Geological Education, 2012, (03): 113-116.

[14] Zhao Pengda. Decision - Given This Opportunity and Innovation Creates Glory-The Speech on "The Geological Society of China Education Research Branch of the Fourth Member of Congress and Geological Education Innovation Seminar” [C]. The Fourth Member of Congress and Geological Education Innovation Seminar, 2006. 